\title{
A molecular analysis of the bacteria present within oral squamous cell carcinoma
}

\section{Correspondence \\ Samuel J. Hooper \\ hoopersj@cardiff.ac.uk}

Received 30 August 2006

Accepted 10 August 2007

\author{
Samuel J. Hooper, ${ }^{1}$ St-John Crean, ${ }^{1}$ Michael J. Fardy, ${ }^{1}$ \\ Michael A. O. Lewis, ${ }^{1}$ David A. Spratt, ${ }^{2}$ William G. Wade ${ }^{3}$ \\ and Melanie J. Wilson ${ }^{1}$
${ }^{1}$ Department of Oral Surgery, Medicine and Pathology, Cardiff University, Cardiff CF14 4XY, UK 256 Gray's Inn Rd, London WC1X 8LD, UK Infection Research Group, London SE1 9RT, UK \\ ${ }^{2}$ Division of Microbial Diseases, Eastman Dental Institute, University College London, \\ ${ }^{3}$ King's College London Dental Institute at Guy's, King's College and St Thomas' Hospitals,
}

\begin{abstract}
In order to characterize the bacterial microbiota present within oral cancerous lesions, tumorous and non-tumorous mucosal tissue specimens (approx. $1 \mathrm{~cm}^{3}$ ) were harvested from ten oral squamous cell carcinoma (OSCC) patients at the time of surgery. Any microbial contamination on the surface of the specimens was eliminated by immersion in Betadine and washing with PBS. Bacteria were visualized within sections of the OSCC by performing fluorescent in situ hybridization with the universal oligonucleotide probe, EUB338. DNA was extracted from each aseptically macerated tissue specimen using a commercial kit. This was then used as template for PCR with three sets of primers, targeting the 16S rRNA genes of Spirochaetes, Bacteroidetes and the domain Bacteria. PCR products were differentiated by TA cloning and bacterial species were identified by partial sequencing of the $16 \mathrm{~S}$ rRNA gene fragments. A total of 70 distinct taxa was detected: 52 different phylotypes isolated from the tumorous tissues, and 37 taxa from within the non-tumorous specimens. Differences between the composition of the microbiotas within the tumorous and non-tumorous mucosae were apparent, possibly indicating selective growth of bacteria within carcinoma tissue. Most taxa isolated from within the tumour tissue represented saccharolytic and aciduric species. Whether the presence of these bacteria within the mucosa has any bearing on the carcinogenic process is a concept worthy of further investigation.
\end{abstract}

\section{INTRODUCTION}

Oral cancer is one of the ten most prevalent cancers in the world (Reichart, 2001; Rosenquist et al., 2005). The prognosis for oral cancers is notably poor, with the mean all-stage, 5-year survival rate being less than $50 \%$ (Kujan et al., 2005; Zakrzewska, 1999). Most worryingly, the incidence of cancer of the oral cavity appears to be increasing in many parts of the world, including the UK (Franceschi et al., 2000; Hindle et al., 2000; Llewellyn et al., 2004; Reichart, 2001; Zakrzewska, 1999). More than $90 \%$ of mouth neoplasms are squamous cell carcinomas (SCCs) originating from the oral mucosa (Chen \& Myers, 2001).

It has been well established that most cases of oral SCC (OSCC) are associated with tobacco use and heavy alcohol

Abbreviations: $\mathrm{FISH}$, fluorescent in situ hybridization; OSCC, oral squamous cell carcinoma; SCC, squamous cell carcinoma.

The GenBank/EMBL/DDBJ accession numbers for the 16S rRNA gene sequences of the novel phylotypes reported in this study are DQ093271-DQ093274. consumption (Ogden, 2005; Warnakulasuriya et al., 2005). However, these risk factors alone do not account for all cases and it is becoming apparent that other factors must play an important aetiological role, particularly in younger patients (Llewellyn et al., 2004). Poor oral hygiene (Lissowska et al., 2003; Rosenquist et al., 2005; Velly et al., 1998), periodontitis (Tezal et al., 2005) and infection with viruses (Ha \& Califano, 2004) or Candida species (Sitheeque \& Samaranayake, 2003) have all been associated independently with oral cancer. Other possible risk factors may include infection with certain species of bacteria.

Interest in the possible relationships between bacteria and the different stages of cancer development has been increasing since the classification by the World Health Organization of Helicobacter pylori as a definite (class 1) carcinogen (Björkholm et al., 2003). Various other bacterial infections have also been found to correlate with an increased risk of developing cancer, for instance, an increased risk of gallbladder carcinoma is associated with Salmonella typhi infection (Dutta et al., 2000; Shukla et al., 
2000) and there is a greater risk of developing colon cancer in Streptococcus bovis-infected patients (Ellmerich et al., 2000; Waisberg \& Matheus, 2002). Such epidemiological links have indirectly implied aetiological roles for these micro-organisms, which has prompted the study of potential mechanisms by which bacterial species may initiate or promote carcinogenesis. These include the induction of chronic inflammation (Coussens \& Werb, 2002; Parsonnet, 1995), by interference, either directly or indirectly, with eukaryotic cell cycle and signalling pathways (Lax, 2005; Lax \& Thomas, 2002), or via the metabolism of potentially carcinogenic substances (Knasmüller et al., 2001; Salaspuro, 2003).

To date, there have been only a few investigations into the possible associations between bacterial species and oral carcinoma. In a study of intraoral carcinomas, Nagy et al. (1998) demonstrated increased numbers of certain members of the oral microbiota on the surface of tumours in comparison with control sites. More recently, it has been reported that patients with OSCC tend to possess significantly raised concentrations of certain bacteria in their saliva (Mager et al., 2005). This apparent alteration of the oral microbiota in cases of OSCC is of particular interest because of its potential application as a diagnostic tool. Other groups have demonstrated the presence of specific bacterial species within tissues from tumours of the upper aerodigestive tract using culture-independent approaches. Species-specific molecular techniques have been used to show the presence of Streptococcus anginosus within tumour specimens from oropharyngeal, oesophageal and gastric carcinoma patients (Narikiyo et al., 2004; Sasaki et al., 1998; Shiga et al., 2001; Tateda et al., 2000). It has also been shown by PCR amplification that Streptococcus mitis and Treponema denticola are significantly more prevalent within oesophageal carcinoma tissues compared with non-tumorous tissue (Narikiyo et al., 2004). However, at the time of writing, no previous studies have attempted to examine comprehensively the bacterial population within oral carcinoma tissue using a 'universal' molecular approach.

Techniques based on the gene encoding $16 \mathrm{~S}$ rRNA are now a standard approach for characterizing the bacterial species present within polymicrobial populations (Amann et al., 2001; Paster et al., 2001; Spratt, 2004; Wade, 2004). The aims of this investigation were twofold: firstly, to determine the location of bacteria within OSCC using fluorescent in situ hybridization (FISH), and, secondly, to identify the species present within tumorous and nontumorous mucosal tissue from OSCC patients, without the biases of culture, by PCR cloning and sequencing of the $16 \mathrm{~S}$ rRNA gene.

\section{METHODS}

Collection of tissue specimens. Tissue specimens were obtained from nine male and one female OSCC patients, with a mean age of $65.3 \pm 9.8$ years. Ethical approval for the study was granted by the South Wales Local Research Ethics Committee and subjects agreed to participate with their informed consent. Tumours were removed surgically and specimens from the resected OSCC were harvested under aseptic conditions. The technique involved the surgeon rescrubbing and placing the specimen on a separate sterile surface. With a new blade for each cut, a $1 \mathrm{~cm}^{3}$ specimen was removed from within the tumorous mass without compromising the pathological margins. At the same time, control specimens consisting of nontumorous tissue harvested at least $5 \mathrm{~cm}$ away from the primary tumour site were also obtained.

Specimens were aseptically transferred to the laboratory in separate vials of a reduced transport medium comprising tryptone $(1 \%, \mathrm{w} / \mathrm{v})$, yeast extract $(0.5 \%, \mathrm{w} / \mathrm{v})$, glucose $(0.1 \%, \mathrm{w} / \mathrm{v})$, cysteine hydrochloride $(0.1 \%, \mathrm{w} / \mathrm{v})$, sodium hydroxide $(50 \mathrm{mM})$ and horse serum $(2 \%, v / v)$, sterilized using a $0.2 \mu \mathrm{m}$ filter.

All subsequent handling of the specimens was carried out using aseptic technique on surfaces cleaned with hycolin phenolic disinfectant $(2 \%, v / v)$. Tissue specimens were placed in Betadine antiseptic solution (Seton Healthcare Group) for $3 \mathrm{~min}$ to disinfect the surface. Subsequently, tissues were vortexed in multiple $500 \mu \mathrm{l}$ aliquots of PBS to encourage the removal of any bacteria on the tissue surface. Final washes were retained and analysed by both culture and culture-independent (PCR) methods to determine whether surface decontamination was successful. Standard clinical cultivation methods were used, culturing washes on non-specific media and under both aerobic and anaerobic conditions, as described previously (Hooper et al., 2006). Specimens were stored in TE buffer at $-80{ }^{\circ} \mathrm{C}$ prior to molecular analysis.

FISH. A portion of SCC tissue from one of the patients mentioned above (male, aged 59 years) was fixed overnight in $10 \%$ formyl saline. This was processed, according to standard clinical pathology protocols (Cross, 2004), through graded alcohols and xylene, and embedded into paraffin wax. Sections of $4 \mu \mathrm{m}$ thick were cut using a microtome and mounted onto SuperFrost glass slides (MenzelGläser). Prior to FISH, sections were pre-treated by submersion in xylene for $5 \mathrm{~min}$. This was repeated a further two times and followed by two immersions in $96 \%$ ethanol ( 5 min each) and then a single immersion in $70 \%$ ethanol $(5 \mathrm{~min})$. Slides were rinsed with sterile PBS ( $1 \mathrm{~min})$ and incubated in $50 \mathrm{mM} \mathrm{TE}$ buffer ( $\mathrm{pH}$ 7.4) containing lysozyme $\left(10 \mathrm{mg} \mathrm{ml}^{-1}\right)$ for $20 \mathrm{~min}$ at $37{ }^{\circ} \mathrm{C}$ to permeablize the cells to the oligonucleotide probe. Following another rinse with PBS, sections were again incubated in $50 \mathrm{mM}$ TE buffer, this time containing proteinase $\mathrm{K}\left(7 \mu \mathrm{g} \mathrm{ml}{ }^{-1}\right.$; Promega), at $37^{\circ} \mathrm{C}(20 \mathrm{~min})$. Subsequent to this incubation, slides were rinsed thoroughly with double-distilled water and immersed in $70 \%$ ethanol (1 min), followed by $96 \%$ ethanol (1 min). After air drying, slides were ready for FISH.

Sections were pre-incubated at $48{ }^{\circ} \mathrm{C}(20 \mathrm{~min})$ in a hybridization buffer $(300 \mu \mathrm{l})$ containing $0.9 \mathrm{M}$ sodium chloride, $20 \mathrm{mM}$ Tris $/ \mathrm{HCl}$ $(\mathrm{pH} 7.4)$ and $0.5 \%(\mathrm{w} / \mathrm{v})$ SDS. Pre-warmed hybridization buffer $(300 \mu \mathrm{l})$ containing $0.1 \mu \mathrm{M}$ oligonucleotide probe EUB338 (5' GCTGCCTCCCGTAGGAGT-3'), which was $5^{\prime}$-end labelled with FITC (MWG Biotech), was carefully applied to the tissue sections. EUB338 is complementary to a portion of the 16S rRNA gene that is highly conserved within the domain Bacteria (Banerjee et al., 2002; Sunde et al., 2003). Following incubation for $3.5 \mathrm{~h}$ in a dark humid chamber at $46{ }^{\circ} \mathrm{C}$, each slide was rinsed thoroughly with sterile double-distilled water and air dried in the dark. Sections were counterstained with $0.025 \%(\mathrm{w} / \mathrm{v})$ concanavalin A-Alexa Fluor 594 conjugate (Molecular Probes) for $20 \mathrm{~min}$. Each slide was again rinsed with water, dried (ending with partial air drying in the dark for $5 \mathrm{~min}$ ) and subsequently mounted with FluoroSave (Calbiochem, Merck Bioscience). As a control, blank slides with no tissue sections were included to confirm that no bacteria were being introduced during the hybridization procedure. 
Hybridized sections were viewed using a Provis AX70 microscope with a built-in incident light fluorescence illuminator (Olympus). Images were obtained using an attached Nikon DXM1200 digital camera and the associated ACT-1 software, version 2.63 (Nikon).

PCR cloning of 16S rRNA gene sequences. Tissue specimens were macerated aseptically and digested with proteinase $\mathrm{K}(2.5 \mu \mathrm{g}$ $\mathrm{ml}^{-1}$ ) overnight at $55{ }^{\circ} \mathrm{C}$. DNA extracts were then prepared using a Puregene DNA isolation kit (Gentra Systems) and the 'DNA Isolation from Gram-positive Bacteria Culture Medium' protocol (http:// www1.qiagen.com/HB/GentraPuregene_EN).

The DNA extracts were each used as the template for three separate PCRs using primers first described by Paster et al. (2001). The three reactions differed only in the reverse primer used, namely either C90 (5'-GTTACGACTTCACCCTCCT-3', specific for Spirochaetes), F01 (5'-CCTTGTTACGACTTAGCCC-3', specific for Bacteroidetes) or E94 (5'-GAAGGAGGTGWTCCARCCGCA-3', specific for the domain Bacteria). All reactions used the universal D88 primer (5'GAGAGTTTGATYMTGGCTCAG-3') as the forward primer. Each reaction mixture comprised $0.5 \mu \mathrm{M}$ of both forward and reverse primers, $200 \mu \mathrm{M}$ each deoxynucleotide, $1.5 \mathrm{mM} \mathrm{MgCl}_{2}$, the working concentration of magnesium-free buffer, $1.5 \mathrm{U}$ Taq polymerase and $5 \mu \mathrm{l}$ DNA extract (approx. 0.5 $\mu \mathrm{g}$ DNA). All PCRs were performed with $8 \mathrm{~min}$ of denaturation at $95{ }^{\circ} \mathrm{C}$, followed by 30 cycles of denaturation at $95{ }^{\circ} \mathrm{C}(45 \mathrm{~s})$, annealing at $60{ }^{\circ} \mathrm{C}(60 \mathrm{~s})$ and extension at $72{ }^{\circ} \mathrm{C}(105 \mathrm{~s}$, increasing by $5 \mathrm{~s}$ each cycle $)$, and a final $72{ }^{\circ} \mathrm{C}$ extension step for $10 \mathrm{~min}$.

Fresh PCR products $(4 \mu \mathrm{l})$ were cloned into Escherichia coli using the commercial vector pCR2.1 available in the TOPO TA cloning kit (Invitrogen Life Technologies). For each tissue specimen, a total of 30 successful clones, representing approximately $10 \%$ of the total transformants (mean of $10.5 \%$ of the successful clones from each specimen), was picked from the three cloning reactions. Overnight cultures of the transformed cells were inoculated into $5 \mathrm{ml}$ LuriaBertani broth containing kanamycin $\left(50 \mu \mathrm{g} \mathrm{ml}^{-1}\right)$ and incubated at $37{ }^{\circ} \mathrm{C}$ for $18 \mathrm{~h}$. Plasmids were purified from each culture using a GenElute Plasmid mini-prep kit (Sigma-Aldrich), following the manufacturer's instructions.

The cloned 16S rRNA gene sequences from each plasmid preparation were amplified using M13 primers, as described by the manufacturer. Products were analysed by standard agarose gel electrophoresis and visualized under UV light. PCR products of approximately $1500 \mathrm{bp}$ were considered to be positive results. If the amplified insert sequences were of any other size, they were assumed to be the result of the formation of chimeric molecules or some other PCR error and were not subjected to sequence analysis.

Identification of cloned isolates. Amplified cloned inserts were purified by precipitation and washing with ethanol. First, $15 \mu \mathrm{l} 5 \mathrm{M}$ $\mathrm{NaCl}$ and $15 \mu \mathrm{l} 40 \%$ polyethylene glycol (molecular mass $8000 \mathrm{Da}$ ) were added to each PCR reaction. This was centrifuged $(16000 \mathrm{~g}$, $15 \mathrm{~min}$ ), and the supernatant aspirated and replaced with $200 \mu \mathrm{l} 70 \%$ ethanol. The centrifugation, aspiration and ethanol washing steps were repeated. Following another centrifugation step, the PCR products were air dried and resuspended in nuclease-free water $(30 \mu \mathrm{l})$.

The $16 \mathrm{~S}$ rDNA PCR products were partially sequenced using primer 357F (5'-CTCCTACGGGAGGCAGCAG-3'; Lane, 1991), ABI Prism BigDye terminator cycle sequencing ready reaction kits and an automated DNA sequencer (ABI PRISM 3100 Genetic Analyzer; Applied Biosystems). This gave reliable sequences of at least $500 \mathrm{nt}$, which were compared to all GenBank DNA sequence entries using the FASTA sequence homology search program (http://www.ebi.ac.uk/ services/index.html; Pearson, 1990).
Whenever this sequence was insufficient to provide a conclusive identification, PCR products were further sequenced using primers 27F (5'-GTGCTGCAGAGAGTTTGATCCTGGCTCAG-3') and 1492R (5'-CACGGATCCTACGGGTACCTTGTTACGACTT-3') (Lane, 1991) to give a sequence of at least $1200 \mathrm{nt}$.

A $>99 \%$ homology to the $16 \mathrm{~S}$ rRNA gene sequence of the type strain, or other suitable reference strain, was the criterion used to identify an isolate to species level. Where more than one reference species exhibited $>99 \%$ sequence homology, the match with the greatest homology was taken as the identity, wherever the sequence was shown to be reproducible and reliable. If there were no significant matches to known strains with currently recognized nomenclature, the database entry from the uncultured or cloned 16S rRNA gene sequence with the greatest $(>99 \%)$ homology was used as the identity. If there were no significant matches to any existing entries, the isolate was named based on the results of the indiscriminate GenBank search.

Possible chimeric sequences were detected by examination with both the online Bellerophon program (http://foo.maths.uq.edu.au/ \%7Ehuber/bellerophon.pl; Huber et al., 2004) and the Ribosomal Database Project's chimera check function (http://35.8.164.52/cgis/ chimera.cgi?su=SSU; Cole et al., 2003).

The null hypothesis that the probability of each phylotype occurring is the same for both types of tissue was tested using two-sided Fisher's exact tests (Agresti, 1992).

\section{RESULTS AND DISCUSSION}

\section{Surface decontamination of tissue specimens}

Surface decontamination of the samples was achieved by immersion in Betadine and washing with PBS, a protocol similar to that used to decontaminate samples in reported work (Morita et al., 2003). This was critical in order to eliminate any organisms occurring naturally on the surface of the tumours or there as a result of salivary or instrument contamination during surgery. The method was validated by PCR, and both aerobic and prolonged anaerobic culture of surface washings, which were found to be negative for the tumorous and non-tumorous control specimens from all ten patients.

\section{FISH}

OSCC tissue was successfully processed and stained with the fluorescent Alexa 594 conjugate. Using the universal eubacterial probe EUB338-FITC, bacteria could be detected by FISH in all sections of OSCC tissue examined. Examples of sections containing fluorescently labelled bacteria are shown in Fig. 1. Bacteria were observed spread throughout the sections among the cells and fibres of the tissue, not just at the tissue border. The bacteria appeared to be present as both individual cells and in larger clumps. At this level of magnification, it was difficult to make out the precise morphologies of the bacteria observed, but most individual cells appeared to be cocci or coccobaccili.

To the best of our knowledge, this is the first investigation where FISH has been used to demonstrate the presence of bacteria within OSCC tissue. In future studies, it may be of interest to examine the stained sections by confocal laser 

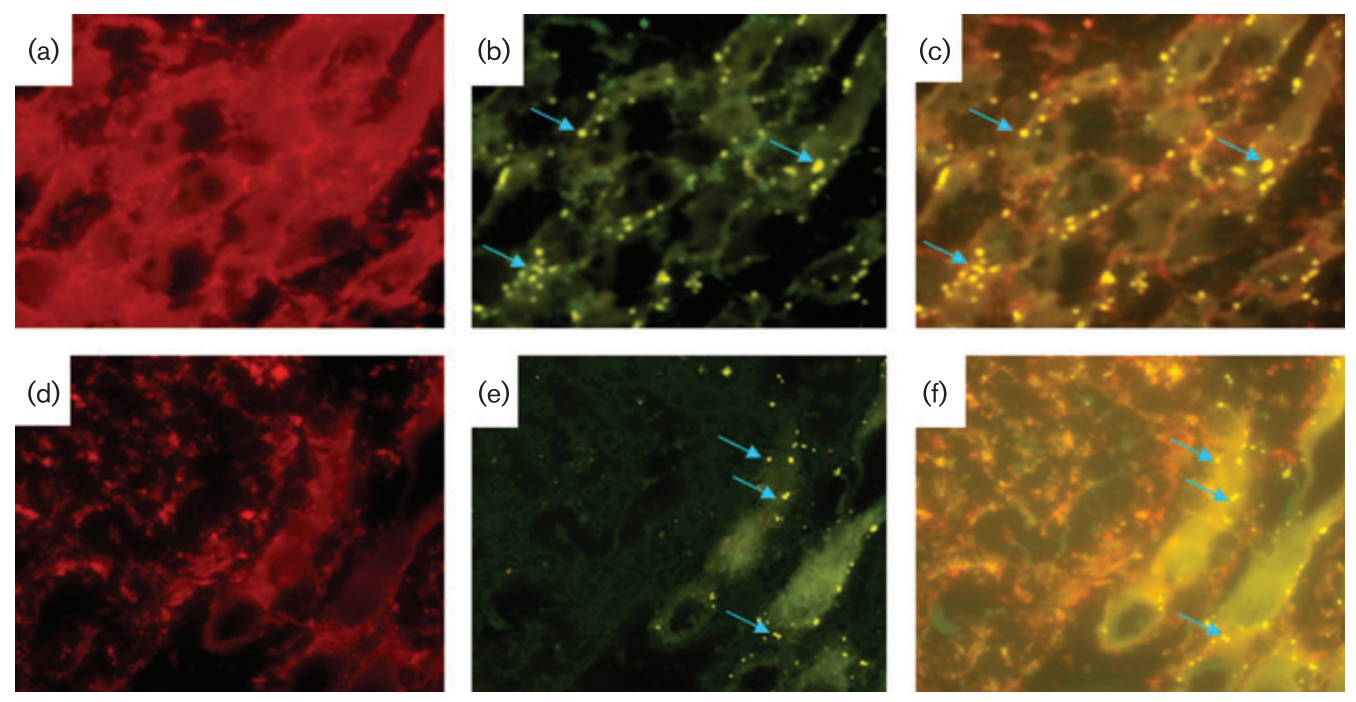

Fig. 1. Images from two different sections of OSCC tumour after staining with both the all-tissue counterstain Alexa Fluor 594 conjugate and the eubacterial probe EUB338-FITC. Section 1 is represented in $(a-c)$ and section 2 in $(d-f)$. Images are shown of the view through a red filter (Alexa Fluor 594) (a,d), the view through a green filter (EUB338-FITC) (b, e) and the composite view of both stains (c, f). Individual bacterial cells hybridized with EUB338-FITC could be observed using the green filter and fluoresced brightly throughout the tissue in all sections. Some examples of bacterial cells are indicated on the photomicrographs by arrows. Magnification $\times 600$.

scanning microscopy, which may well provide significantly more information regarding the location of the bacteria (Thurnheer et al., 2004) and allow us to quantify the bacteria present. However, it should be noted that biases in hybridization and from differing ribosome contents per cell are problems inherent to FISH that limit quantification (Moter \& Göbel, 2000). Additionally, although it has been somewhat validated by its use in numerous studies, there is some evidence that the probe EUB338 will not hybridize to all bacteria in a sample with equal efficiency (Vaahtovuo et al., 2005). Nevertheless, the distribution of bacteria in the sections suggested that these micro-organisms are found throughout the tumour tissue and do not represent contaminants present solely on the tissue surface.

\section{Identification of bacteria by 16S rRNA gene cloning and sequencing}

Species-specific PCR primers have been used in other studies to detect individual bacterial groups in tissue from OSCC patients (Morita et al., 2003; Narikiyo et al., 2004; Shiga et al., 2001; Tateda et al., 2000). However, to the best of our knowledge, this is the first time that PCR with nonspecific, universal primers has been used to characterize the range of bacteria present in OSCC.

PCR amplification and sequence analysis of 16S rRNA genes is a versatile technique and has been used extensively to assess microbial diversity. It is important to remember, however, that the technique relies on the assumption that the gene sequences of all bacteria present in the sample are complementary to the universal primers used. Recent discoveries of new taxa have indicated that several standard 'universal' 16S rRNA gene primers do not recognize all species of bacteria, and that current 16S rRNA gene libraries are not representative of true prokaryotic biodiversity (Baker et al., 2003). However, the three primer sets chosen for this study have been well validated through their use in the characterization of the species present in several oral bacterial communities. These primers have, in the past, been successful in detecting bacteria from 11 distinct phyla, including Acidobacteria, Actinobacteria, Bacteroidetes, Deferribacteres, Deinococcus, Fusobacteria, Firmicutes, Proteobacteria, Spirochaetes and two phyla with no currently known cultivable representatives, namely TM7 and Obsidian Pool OB11 (Aas et al., 2005; Becker et al., 2002; Kazor et al., 2003; Paster et al., 2001, 2002). That said, in this study, taxa from just five phyla were detected, and these were all amplified by the universal primer pair, D88 and E90. PCR with the Bacteroidetesspecific F01 primer resulted in relatively few clones, all of which were also represented by the universal pair. In this study, the Spirochaetes-specific primer, C90, resulted in no detectable PCR product and no successful clones. This was surprising given the previously reported presence of Treponema denticola in similar SCC tissues from oesophageal cancers (Narikiyo et al., 2004). This apparent redundancy between primer sets meant that the results of the cloning were pooled and a single library of sequences constructed (Table 1).

A diversity of bacteria was detected from within both tumorous and non-tumorous tissue specimens. Of the 600 clones screened, a total of 526 16S rRNA sequences was 
Table 1. Phylotypes isolated from tissue specimens by PCR cloning and sequencing of $16 \mathrm{~S}$ rRNA genes

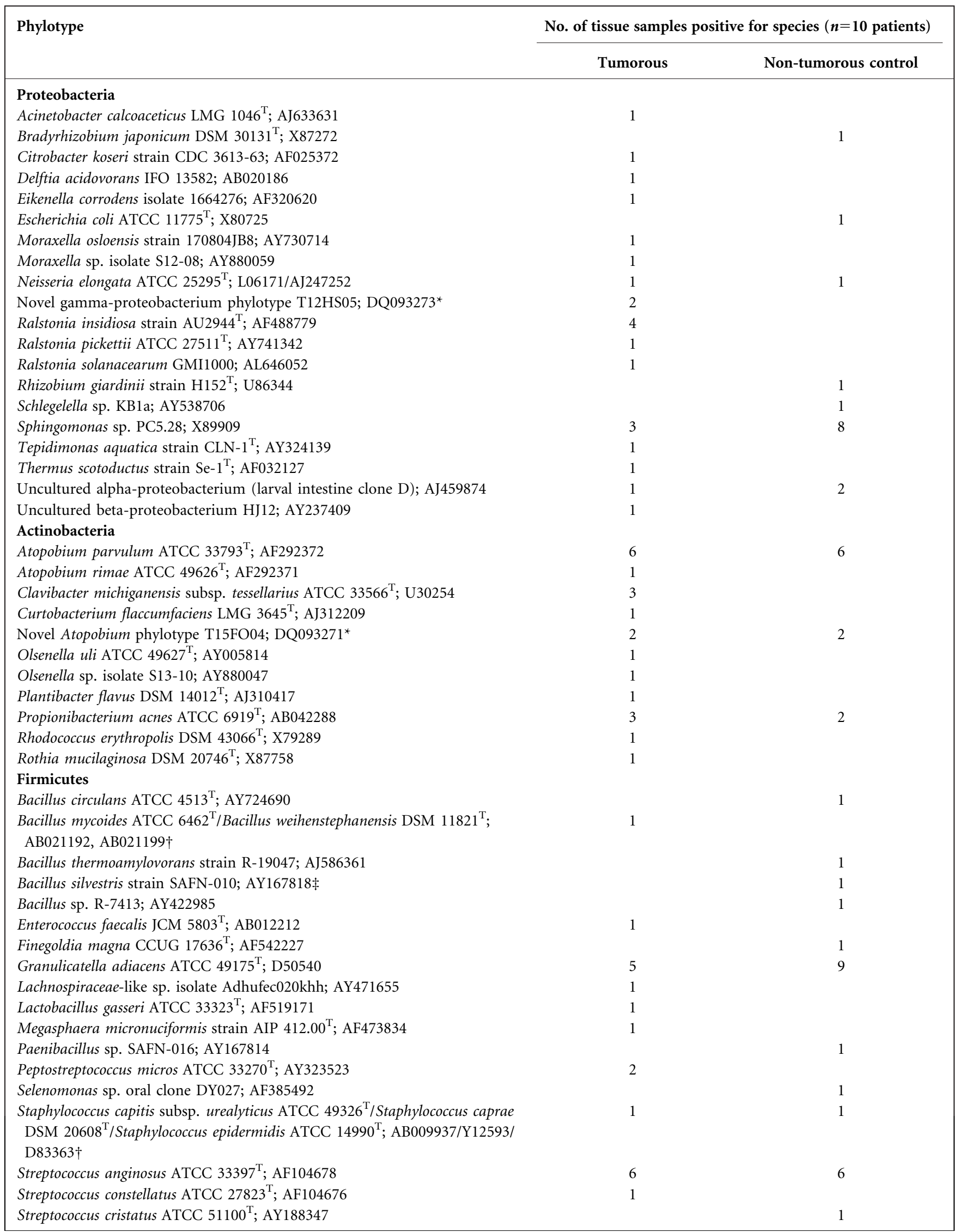


Table 1. cont.

\begin{tabular}{|c|c|c|}
\hline \multirow[t]{2}{*}{ Phylotype } & \multicolumn{2}{|c|}{ No. of tissue samples positive for species ( $n=10$ patients) } \\
\hline & Tumorous & Non-tumorous control \\
\hline Streptococcus gordonii ATCC $10558^{\mathrm{T}}$; AY485606 & & 1 \\
\hline Streptococcus intermedius ATCC $27335^{\mathrm{T}}$; AF104671 & & 1 \\
\hline $\begin{array}{l}\text { Streptococcus mitis ATCC } 49456 / \text { Streptococcus oralis ATCC } 35037^{\mathrm{T}} \text {; AY485601/ } \\
\text { AY485602† }\end{array}$ & & 3 \\
\hline Streptococcus parasanguinis ATCC $15912^{\mathrm{T}}$; AY485605 & 6 & 5 \\
\hline Streptococcus salivarius ATCC $7073^{\mathrm{T}}$; AY188352 & & 1 \\
\hline Veillonella atypica ATCC $17744^{\mathrm{T}}$; AF439641 & 6 & 5 \\
\hline Veillonella dispar ATCC $17748^{\mathrm{T}}$; AF439639 & 2 & 1 \\
\hline \multicolumn{3}{|l|}{ Bacteroides } \\
\hline Capnocytophaga sp. isolate S12-14; AY880056 & 1 & \\
\hline Capnocytophaga sp. oral strain S3; AY005073 & 5 & 3 \\
\hline Novel Capnocytophaga phylotype N17LB09; DQ093272* & 1 & 2 \\
\hline Porphyromonas gingivalis ATCC $33277^{\mathrm{T}}$; AF414809 & & 4 \\
\hline Prevotella intermedia ATCC $25611^{\mathrm{T}} ; \mathrm{X} 73965$ & 1 & \\
\hline Prevotella melaninogenica ATCC $25845^{\mathrm{T}}$; AY323525 & 1 & 3 \\
\hline Prevotella nigrescens ATCC $33563^{\mathrm{T}}$; AF414833 & 3 & 2 \\
\hline Prevotella veroralis ATCC $33779^{\mathrm{T}}$; AY836507 & 2 & 1 \\
\hline Prevotella sp. oral clone BE073; AF385551 & 5 & 1 \\
\hline Uncultured eubacterium E1-K12; AJ289169 & & 1 \\
\hline \multicolumn{3}{|l|}{ Fusobacteria } \\
\hline $\begin{array}{l}\text { Fusobacterium canifelinum RMA } 1036^{\mathrm{T}} / \text { Fusobacterium nucleatum ssp. } \\
\text { nucleatum ATCC } 25586^{\mathrm{T}} \text {; AY162221/AJ133496 } \dagger\end{array}$ & 1 & \\
\hline Fusobacterium naviforme NCTC 11464; AJ006965 & 4 & \\
\hline Leptotrichia shahii strain LB $37^{\mathrm{T}}$; AY029806 & 1 & \\
\hline Novel Leptotrichia phylotype N16LA25; DQ093274* & 3 & 5 \\
\hline Total & 52 & 37 \\
\hline
\end{tabular}

T, Type strain.

${ }^{\star}$ Novel phylotypes detected in this study.

$\dagger$ These cloned phylotypes exhibited equivalent homology to the multiple type strains documented.

$\ddagger$ The only named strain for which the cloned sequence is a significant match (Bacillus silvestris SAFN-010, AY167818) seems distinct from any other strain of the same species. This strain of Bacillus silvestris and the corresponding phylotype isolated in this study both exhibited only an approximately $96 \%$ match to the $16 \mathrm{~S}$ rRNA gene sequences in the public databases from other B. silvestris strains, including the type strain (GenBank no. AJ006086).

determined, 277 from the tumorous specimens and 249 from the non-tumorous control tissues. The remaining 74 clones ( $12.3 \%$ of the total) produced M13 PCR products of sizes other than approximately $1500 \mathrm{bp}$, and so were assumed to be chimeric molecules and were not analysed further. Of the sequenced clones, 25 (4.75\% of the total) had no matches to any existing entries in the databases and were found from only one specimen. It was impossible to determine whether these represented chimeric molecules and so they were not included in further analyses.

Of the sequenced phylotypes, all but four matched previous entries in GenBank that originated from other cultureindependent studies. The four with no significant matches to any previously existing entries in the public database were each isolated from more than one specimen, so it seems unlikely that they arose from the creation of chimeras. These four phylotypes included phylotype
T15FO04 (98.4\% homology to the type strain of Atopobium parvulum; GenBank accession no. AF292372), phylotype N17LB09 (98.7\% sequence similarity to Capnocytophaga gingivalis strain LMG 12118; GenBank accession no. U41346), phylotype N16LA25 (98.7\% match to the type strain of Leptotrichia wadei; GenBank accession no. AY029802) and phylotype T12HS05 (95.1\% match to the Xanthomonadaceae 'Bacterium SG-3'; GenBank accession no. AF548381). The first three of these in particular were very close in sequence to known species but, as they were isolated here several times from several sources and the sequencing was reproducible in each case, they appeared to represent novel phylotypes and accordingly were submitted to GenBank (accession numbers DQ093271, DQ093272, DQ093274 and DQ093273, respectively).

Several unusual bacteria, not usually associated with human clinical samples, were detected in this study. In addition to the novel phylotypes, these included, from the 
tumorous tissues, Clavibacter michiganensis, Plantibacter flavus, Tepidimonas aquatica and Thermus scotoductus, and from the non-tumorous tissues, Bacillus thermoamylovorans, Bradyrhizobium japonicum and Rhizobium giardinii. All of these have, to the best of our knowledge, only previously been isolated from non-clinical sources. Each was only detected in relatively small amounts, namely single clones from single specimens, and none was also isolated by culture (Hooper et al., 2006), suggesting that they may have been transients and were not present in the tissues as living cells. Alternatively, these unusual environmental bacteria, present in low quantities, may have been the result of contamination. DNA from environmental species of bacteria has been reported as a possible contaminant of DNA extraction solutions (Tanner et al., 1998). Similarly, DNA from both Escherichia coli and Thermus species, single clones of which were isolated here, and other unidentified species, have reportedly been found contaminating PCR reagents (Hughes et al., 1994). Such problems of contaminants in commercial reagents are known, and standard sterile techniques were used to minimize further contamination and reduce the risk of 'false-positive' PCR products. It is interesting to note that Mohammadi et al. (2005) recently reported some success in eliminating contaminant DNA by filtering reagents through a DNA-isolating column prior to use. It may be worth incorporating this step into any future work in order to reduce contamination further and possibly to elucidate the origin of the suspect bacterial DNA.

Overall, 70 distinct taxa were detected (see Table 1). From the tumorous tissues, 52 phylotypes were identified, a mean of 10.3 taxa per sample. Slightly fewer phylotypes were isolated from the non-tumorous specimens, a total of 37 distinct taxa (a mean of 8.8 taxa per sample). The use of a paired-sample $t$-test indicated that this difference was not significant $(P=0.173)$. Two-sided Fisher's exact tests for each of the phylotypes revealed no significant differences $(P>0.05$ for all taxa) between the numbers of positive tissue samples detected in the two types of specimen (Table 1). However, the lack of statistical significance is not surprising given the relatively low total numbers of specimens and the high number of taxa isolated. Nevertheless, several interesting trends were observed. For instance, when considering the relative numbers of samples positive for each bacterium, four taxa were isolated in $\geqslant 30 \%$ more of the control specimens than in the tumorous specimens, namely Granulicatella adiacens, Porphyromonas gingivalis, Sphingomonas sp. PC5.28 and Streptococcus mitis/oralis. Similarly, Clavibacter michiganensis subsp. tessellarius, Fusobacterium naviforme and Ralstonia insidiosa were all detected in $\geqslant 30 \%$ more of the tumorous than non-tumorous samples. These differences could be indicative of real changes in the microbiota present within the mucosal tissue of these patients.

The majority of species found within the tumorous tissues were saccharolytic and aciduric, reflecting, perhaps, the selective nature of the acidic and hypoxic microenvironment found within tumours (Raghunand et al., 2003). For instance, Proteobacteria, and members of the genera Fusobacterium, Streptococcus, Prevotella and Veillonella, are all known to be capable of surviving at relatively low pH (Curtis et al., 2002; Marchant et al., 2001; Svensäter et al., 1997; Takahashi, 2003). Indeed, most of the taxa isolated from the tumorous samples in this study have previously been detected in acidic dental caries lesions (Chhour et al., 2005; Munson et al., 2004). A similar trend was apparent when these tissue specimens were analysed previously by culture analysis (Hooper et al., 2006). Many of the species detected by PCR cloning were also cultivated from OSCC tumour and control samples, indicating that the bacteria found to be present within the tissue in this study could well have been viable in vivo. The cultural analysis also found a slightly higher number of taxa in the tumorous tissues than in the non-tumorous specimens, a trend that was repeated in this study (a total of 52 separate phylotypes were isolated from the tumorous compared with the 37 taxa from the non-tumorous tissues). That different taxa were isolated by the culture and cultureindependent approaches reflects the different specificities and species-dependent biases of the two methods, as has been reported previously (Davies et al., 2004; Munson et al., 2002; Wilson et al., 1997). It is worth remembering that all of the steps involved in isolating bacterial taxa from a polymicrobial source by PCR cloning may have some biases, which in turn may skew the results (Spratt, 2004).

Of particular interest was the isolation of Streptococcus anginosus from six patients in this present study. This species has been detected in OSCC specimens in the past (Tateda et al., 2000; Morita et al., 2003), and has been implicated in the process of carcinogenesis due both to its association with tumours and to its ability to induce inflammation (Sasaki et al., 2001; Sugano et al., 2003).

The implications of the presence of a diversity of viable bacteria deep within the tissue of SCC are unclear. As most of the taxa detected here are known members of the oral microbiota, it would seem that the bacteria within the tumour and mucosal tissue originated from the oral cavity. This would support reported studies that have suggested that oral bacteria are capable of translocating from the mucosal surfaces of oral cancer patients into the regional lymph nodes, presumably via the cancerous lesion (Sakamoto et al., 1999). However, it is also worth noting that, in animal models, bacteria present in the blood have been shown to seed preferentially to tumours ( $\mathrm{Yu}$ et al., 2004).

The apparent differences between the microbiota of the tumour and control tissues suggests a degree of bacterial specificity that merits further study. Furthermore, as evidence that bacteria are involved in the development of many different cancers increases, it is interesting to speculate that the species found in this study may play a role in the processes of carcinogenesis. Whether these 
bacteria simply represent later secondary colonizers or whether bacterial-host interactions have significant effects on carcinogenesis are ideas worthy of further investigation.

\section{REFERENCES}

Aas, J. A., Paster, B. J., Stokes, L. N., Olsen, I. \& Dewhirst, F. E. (2005). Defining the normal bacterial flora of the oral cavity. J Clin Microbiol 43, 5721-5732.

Agresti, A. (1992). A survey of exact inference for contingency tables. Stat Sci 7, 131-153.

Amann, R., Fuchs, B. M. \& Behrens, S. (2001). The identification of microorganisms by fluorescence in situ hybridisation. Curr Opin Biotechnol 12, 231-236.

Baker, G. C., Smith, J. J. \& Cowan, D. A. (2003). Review and re-analysis of domain-specific 16S primers. J Microbiol Methods 55, 541-555.

Banerjee, A., Yasseri, M. \& Munson, M. (2002). A method for the detection and quantification of bacteria in human carious dentine using fluorescent in situ hybridisation. J Dent 30, 359-363.

Becker, M. R., Paster, B. J., Leys, E. J., Moeschberger, M. L., Kenyon, S. G., Galvin, J. L., Boches, S. K., Dewhirst, F. E. \& Griffen, A. L. (2002). Molecular analysis of bacterial species associated with childhood caries. J Clin Microbiol 40, 1001-1009.

Björkholm, B., Falk, P., Engstrand, L. \& Nyrén, O. (2003). Helicobacter pylori: resurrection of the cancer link. J Intern Med 253, 102-119.

Chen, A. Y. \& Myers, J. N. (2001). Cancer of the oral cavity. Dis Mon 47, 275-361.

Chhour, K. L., Nadkarni, M. A., Byun, R., Martin, F. E., Jacques, N. A. \& Hunter, N. (2005). Molecular analysis of microbial diversity in advanced caries. J Clin Microbiol 43, 843-849.

Cole, J. R., Chai, B., Marsh, T. L., Farris, R. J., Wang, Q., Kulam, S. A., Chandra, S., McGarrell, D. M., Schmidt, T. M. \& other authors (2003). The Ribosomal Database Project (RDP-II): previewing a new autoaligner that allows regular updates and the new prokaryotic taxonomy. Nucleic Acids Res 31, 442-443.

Coussens, L. M. \& Werb, Z. (2002). Inflammation and cancer. Nature 420, 860-867.

Cross, S. S. (2004). Diagnostic pathology in clinical practice. In General and Systematic Pathology, 4th edn, pp. 57-70. Edited by J. C. E. Underwood. London: Churchill Livingstone.

Curtis, P., Nakatsu, C. H. \& Konopka, A. (2002). Aciduric proteobacteria isolated from pH 2.9 soil. Arch Microbiol 178, 65-70.

Davies, C. E., Hill, K. E., Wilson, M. J., Stephens, P., Hill, C. M., Harding, K. G. \& Thomas, D. W. (2004). Use of 16 S ribosomal DNA PCR and denaturing gradient gel electrophoresis for analysis of the microbiotas of healing and nonhealing chronic venous leg ulcers. J Clin Microbiol 42, 3549-3557.

Dutta, U., Garg, P. K., Kumar, R. \& Tandon, R. K. (2000). Typhoid carriers among patients with gallstones are at increased risk for carcinoma of the gallbladder. Am J Gastroenterol 95, 784-787.

Ellmerich, S., Schöller, M., Duranton, B., Gossé, F., Galluser, M., Klein, J.-P. \& Raul, F. (2000). Promotion of intestinal carcinogenesis by Streptococcus bovis. Carcinogenesis 21, 753-756.

Franceschi, S., Bidoli, E., Herrero, R. \& Muñoz, N. (2000). Comparison of cancers of the oral cavity and pharynx worldwide: etiological clues. Oral Oncol 36, 106-115.

Ha, P. K. \& Califano, J. A. (2004). The role of human papillomavirus in oral carcinogenesis. Crit Rev Oral Biol Med 15, 188-196.
Hindle, I., Downer, M. C., Moles, D. R. \& Speight, P. M. (2000). Is alcohol responsible for more intra-oral cancer? Oral Oncol 36, 328-333.

Hooper, S. J., Crean, S., Lewis, M. A. O., Spratt, D. A., Wade, W. G. \& Wilson, M. J. (2006). Viable bacteria present within oral squamous cell carcinoma tissue. J Clin Microbiol 44, 1719-1725.

Huber, T., Faulkner, G. \& Hugenholtz, P. (2004). Bellerophon: a program to detect chimeric sequences in multiple sequence alignments. Bioinformatics 20, 2317-2319.

Hughes, M. S., Beck, L.-A. \& Skuce, R. A. (1994). Identification and elimination of DNA sequences in Taq DNA polymerase. J Clin Microbiol 32, 2007-2008.

Kazor, C. E., Mitchell, P. M., Lee, A. M., Stokes, L. N., Loesche, W. J., Dewhirst, F. E. \& Paster, B. J. (2003). Diversity of bacterial populations on the tongue dorsa of patients with halitosis and healthy patients. J Clin Microbiol 41, 558-563.

Knasmüller, S., Steinkellner, H., Hirschl, A. M., Rabot, S., Nobis, E. C. \& Kassie, F. (2001). Impact of bacteria in dairy products and of the intestinal microbiota on the genotoxic and carcinogenic effects of heterocyclic aromatic amines. Mutat Res 480-481, 129-138.

Kujan, O., Glenny, A.-M., Duxbury, J., Thakker, N. \& Sloan, P. (2005). Evaluation of screening strategies for improving oral cancer mortality: a Cochrane systematic review. J Dent Educ 69, 255-265.

Lane, D. J. (1991). 16S/23S rRNA sequencing. In Nucleic Acid Techniques in Bacterial Systematics, pp. 115-175. Edited by E. Stackebrandt \& M. Goodfellow. Chichester: Wiley.

Lax, A. J. (2005). Bacterial toxins and cancer - case to answer? Nat Rev Microbiol 3, 343-349.

Lax, A. J. \& Thomas, W. (2002). How bacteria could cause cancer: one step at a time. Trends Microbiol 10, 293-299.

Lissowska, J., Pilarska, A., Pilarski, P., Samolczyk-Wanyura, D., Piekarczyk, J., Bardin-Mikolajczak, A., Zatonski, W., Herrero, W., Muñoz, N. \& Franceschi, S. (2003). Smoking, alcohol, diet, dentition and sexual practices in the epidemiology of oral cancer in Poland. Eur J Cancer Prev 12, 25-33.

Llewellyn, C. D., Linklater, K., Bell, J., Johnson, N. W. \& Warnakulasuriya, S. (2004). An analysis of risk factors for oral cancer in young people: a case-control study. Oral Oncol 40, 304-313.

Mager, D. L., Haffajee, A. D., Devlin, P. M., Norris, C. M., Posner, M. R. \& Goodson, J. M. (2005). The salivary microbiota as a diagnostic indicator of oral cancer: a descriptive, non-randomized study of cancer-free and oral squamous cell carcinoma subjects. J Transl Med 3, 27.

Marchant, S., Brailsford, S. R., Twomey, A. C., Roberts, G. J. \& Beighton, D. (2001). The predominant microbiota of nursing caries lesions. Caries Res 35, 397-406.

Mohammadi, T. H., Reesink, W., Vandenbroucke-Grauls, C. M. J. E. \& Savelkoul, P. H. M. (2005). Removal of contaminating DNA from commercial nucleic acid extraction kit reagents. J Microbiol Methods 61, 285-288.

Morita, E., Narikiyo, M., Yano, A., Nishimura, E., Igaki, H., Sasaki, H., Terada, M., Hanada, N. \& Kawabe, R. (2003). Different frequencies of Streptococcus anginosus infection in oral cancer and esophageal cancer. Cancer Sci 94, 492-496.

Moter, A. \& Göbel, U. B. (2000). Fluorescence in situ hybridization (FISH) for direct visualization of microorganisms. J Microbiol Methods 41, 85-112.

Munson, M. A., Pitt-Ford, T., Chong, B., Weightman, A. \& Wade, W. G. (2002). Molecular and cultural analysis of the microbiota associated with endodontic infections. J Dent Res 81, 761-766.

Munson, M. A., Banerjee, A., Watson, T. F. \& Wade, W. G. (2004). Molecular analysis of the microbiota associated with dental caries. $J$ Clin Microbiol 42, 3023-3029. 
Nagy, K. N., Sonkodi, I., Szöde, I., Nagy, E. \& Newman, H. N. (1998). The microbiota associated with human oral carcinomas. Oral Oncol 34, 304-308.

Narikiyo, M., Tanabe, C., Yamada, Y., Igaki, H., Tachimori, Y., Kato, H., Muto, M., Montesano, R., Sakamoto, H. \& other authors (2004). Frequent and preferential infection of Treponema denticola, Streptococcus mitis, and Streptococcus anginosus in esophageal cancers. Cancer Sci 95, 569-574.

Ogden, G. R. (2005). Alcohol and oral cancer. Alcohol 35, 169-173.

Parsonnet, J. (1995). Bacterial infection as a cause of cancer. Environ Health Perspect 103, 263-268.

Paster, B. J., Boches, S. K., Galvin, J. L., Ericson, R. E., Lau, C. N., Levanos, V. A., Sahasrabudhe, A. \& Dewhirst, F. E. (2001). Bacterial diversity in human subgingival plaque. J Bacteriol 183, 3770-3783.

Paster, B. J., Falkner, W. A., Jr, Enwonwu, C. O., Idigbe, E. O., Savage, K. O., Levanos, V. A., Tamer, M. A., Ericson, R. L., Lau, C. N. \& Dewhirst, F. E. (2002). Prevalent bacterial species and novel phylotypes in advanced noma lesions. J Clin Microbiol 40, 2187-2191.

Pearson, W. R. (1990). Rapid and sensitive sequence comparison with FASTP and FASTA. Methods Enzymol 183, 63-98.

Raghunand, N., Gatenby, R. A. \& Gillies, R. J. (2003). Microenvironmental and cellular consequences of altered blood flow in tumours. Br J Radiol 76, S11-S22.

Reichart, P. A. (2001). Identification of risk groups for oral precancer and cancer and preventive measures. Clin Oral Investig 5, 207-213.

Rosenquist, K., Wennerberg, J., Schildt, E.-B., Bladström, A., Hansson, B. G. \& Andersson, G. (2005). Oral status, oral infections and some lifestyle factors as risk factors for oral and oropharyngeal squamous cell carcinoma. A population-based case-control study in southern Sweden. Acta Otolaryngol 125, 1327-1336.

Sakamoto, H., Naito, H., Ohta, Y., Tanakna, R., Maeda, N., Sasaki, J. \& Nord, C. E. (1999). Isolation of bacteria from cervical lymph nodes in patients with oral cancer. Arch Oral Biol 44, 789-793.

Salaspuro, M. P. (2003). Acetaldehyde, microbes, and cancer of the digestive tract. Crit Rev Clin Lab Sci 40, 183-208.

Sasaki, H., Ishizuka, T., Muto, M., Nezu, M., Nakanishi, Y., Inagaki, Y., Watanabe, H., Watanabe, H. \& Terada, M. (1998). Presence of Streptococcus anginosus DNA in esophageal cancer, dysplasia of esophagus, and gastric cancer. Cancer Res 58, 2991-2995.

Sasaki, M., Ohara-Nemoto, Y., Tajika, S., Kobayashi, M., Yamaura, C. \& Kimura, S. (2001). Antigenic characterisation of a novel Streptococcus anginosus antigen that induces nitric oxide synthesis by murine peritoneal exudate cells. J Med Microbiol 50, 952-958.

Shiga, K., Tateda, M., Saijo, S., Hori, T., Sato, I., Tateno, H., Matsuura, K., Takasaka, T. \& Miyagi, T. (2001). Presence of Streptococcus infection in extra-oropharyngeal head and neck squamous cell carcinoma and its implication in carcinogenesis. Oncol Rep 8, 245-248.

Shukla, V. K., Singh, H., Pandley, M., Upadhyay, S. K. \& Nath, G. (2000). Carcinoma of the gallbladder - is it a sequel of typhoid? Dig Dis Sci 45, 900-903.

Sitheeque, M. A. M. \& Samaranayake, L. P. (2003). Chronic hyperplastic candidosis/candidiasis (candidal leukoplakia). Crit Rev Oral Biol Med 14, 253-267.
Spratt, D. A. (2004). Significance of bacterial identification by molecular biology methods. Endod Topics 9, 5-14.

Sugano, N., Yokoyama, K., Oshikawa, M., Kumagai, K., Takane, M., Tanaka, H. \& Ito, K. (2003). Detection of Streptococcus anginosus and 8-hydroxy-deoxyguanosine in saliva. J Oral Sci 45, 181-184.

Sunde, P. T., Olsen, I., Göbel, U. B., Theegarten, D., Winter, S., Debelian, G. J., Tronstad, L. \& Moter, A. (2003). Fluorescence in situ hybridization (FISH) for direct visualization of bacteria in periapical lesions of asymptomatic root-filled teeth. Microbiology 149, 1095-1102.

Svensäter, G., Larsson, U.-B., Greif, E. C. G., Cvitkovitch, D. G. \& Hamilton, I. R. (1997). Acid tolerance response and survival by oral bacteria. Oral Microbiol Immunol 12, 266-273.

Takahashi, N. (2003). Acid-neutralizing activity during amino acid fermentation by Porphyromonas gingivalis, Prevotella intermedia and Fusobacterium nucleatum. Oral Microbiol Immunol 18, 109-113.

Tanner, M. A., Goebel, B. M., Dojka, M. A. \& Pace, N. R. (1998). Specific ribosomal DNA sequences from diverse environmental settings correlate with experimental contaminants. Appl Environ Microbiol 64, 3110-3113.

Tateda, M., Shiga, K., Saijo, S., Sone, M., Hori, T., Yokoyama, J., Matsuura, K., Takasaka, T. \& Miyagi, T. (2000). Streptococcus anginosus in head and neck squamous cell carcinoma: implication in carcinogenesis. Int J Mol Med 6, 699-703.

Tezal, M., Grossi, S. G. \& Genco, R. J. (2005). Is periodontitis associated with oral neoplasms? J Periodontol 76, 406-410.

Thurnheer, T., Gmur, R. \& Guggenheim, B. (2004). Multiplex FISH analysis of a six-species bacterial biofilm. J Microbiol Methods 56, 37-47.

Vaahtovuo, J., Korkeamäki, M., Munukka, E., Viljanen, M. K. \& Toivanen, P. (2005). Quantification of bacteria in human feces using 16S rRNA-hybridization, DNA-staining and flow cytometry. J Microbiol Methods 63, 276-286.

Velly, A. M., Franco, E. L., Schlecht, N., Pintos, J., Kowalski, L. P., Oliveira, B. V. \& Curado, M. P. (1998). Relationship between dental factors and risk of upper aerodigestive tract cancer. Oral Oncol 34, 284-291.

Wade, W. G. (2004). Non-culturable bacteria in complex commensal populations. Adv Appl Microbiol 54, 93-106.

Waisberg, J. \& Matheus, C. de O. (2002). Infectious endocarditis from Streptococcus bovis associated with colonic carcinoma: case report and literature review. Arq Gastroenterol 39, 177-180.

Warnakulasuriya, S., Sutherland, G. \& Scully, C. (2005). Tobacco, oral cancer, and treatment of dependence. Oral Oncol 41, 244-260.

Wilson, M. J., Weightman, A. J. \& Wade, W. G. (1997). Applications of molecular ecology in the characterization of uncultured microorganisms associated with human disease. Rev Med Microbiol 8, 91-102.

Yu, Y. A., Shabahang, S., Timiryasova, T. M., Zhang, Q., Beltz, R., Gentschev, I., Goebel, W. \& Szalay, A. A. (2004). Visualization of tumors and metastases in live animals with bacteria and vaccinia virus encoding light-emitting proteins. Nat Biotechnol 22, 313-320.

Zakrzewska, J. M. (1999). Fortnightly review: oral cancer. BMJ 318, 1051-1054. 